\title{
The Change in Thinking about Social Integration of People with Disabilities in Educational Context
}

\author{
Jolanta Lipińska - Lokś / e-mail: jolanta.lipinska-loks@uwr.edu.pl \\ Institute of Pedagogy, University of Wrocław, Poland
}

Lipińska - Lokś, J. (2020). The Change in Thinking about Social Integration of People with Disabilities in Educational Context. Czech-Polish Historical and Pedagogical Journal 12/2, 43-52.

https://doi.org/10.5817/cphpj-2020-021

The idea of social integration of people with disabilities is widely known, accepted and implemented in many areas of social life. It should be noted, however, that in more than forty years history of promoting integration in Poland, significant changes regarding the very concept of integration and understanding the determinants of its effects have been visible. The experience of teachers undertaking integrative teaching and scientific reflection have been the source of these changes, changes regarding: static (state)/dynamic (process) approach to integration, individual/social dimension of integration of people with disabilities, total/fragmentary nature of social integration are the most radical.

In the aspect of changes in terms of social integration, particular attention is devoted to the conditions of integration in education of children with disabilities: positive attitudes of children towards disabled peers, preparation of a child with disability for integration, teacher - his knowledge, skills, attitude.

Key words: disability; people with and without disabilities; social integration; changes in understanding the essence and determinants of the phenomenon; integration in education; pupil with a disability

The idea of social integration of people with disabilities - initiated in the sixties of the last century, widespread first in the United States and in some Scandinavian countries, transferred to Poland in the seventies - is now widely known, accepted and implemented in many areas of social life. Due to the significance of the problem of social integration, the term "integration“ has received numerous interpretations.

In modern special education - which is the most interesting for us, due to the subject of the article, social integration is understood as interdisciplinary, integrated action aimed at the revalidation of individuals who differ from the norm. 1

1 Hoffman, B. (1978). Indywidualne i społeczne aspekty rozwoju integracji w pedagogice specjalnej. Szkoła Specjalna, no 3. 
According to A. Hulk, integration, is expressed in such mutual relationship of people with and without disabilities, in which the same rights are respected, the same values matter and in which identical conditions of maximum, comprehensive development are created for both groups. Integration allows a person with a disability to be himself among others. Integration in this meaning can be applied to all spheres of life of an individual with disability - family life, general and vocational education, work, free time, social and political activity, etc.". ${ }^{2}$

According to A. Maciarz, social integration of people with disabilities is "the idea, the direction of changes and the way of organizing activites and rehabilitation of people with disabilities, which aims to create for those people the opportunity to participate in normal life, to provide access to all the institutions and social situations in which people without disability participate and to shape positive attitudes and psycho-social ties between people with and without disabilities. By integrating disabled children socially, we create conditions for them to be brought up in their families, learn in public schools and grow in natural environment among peers without disabilities". ${ }^{3}$ The essence of social integration is constituted when people with disabilities are included in their living environment so that they feel fully belonging to it and when their diversity is natural. ${ }^{4}$

The multidimensionality of integration phenomenon is indicated by A. Krause, who, analyzing the systems of features describing the phenomenon of integration in various interpretations, distinguishes four basic areas of the concept of integration:

a) integration may be considered as a state or process;

b) integration can be treated as the goal or the method of achieving the goal;

c) integration can be treated as a individual or social problem;

d) integration may be described as a task or condition for the implementation of that task. ${ }^{5}$

The complete picture of this phenomenon emerges from so many interpretations of the term integration and concepts of social integration of people with disabilities.

It should be noted however that such as the general acceptance of integration and its implementation took place in different countries at various pace, also

2 Hulek, A. - Grochmal - Bach, B. (eds.) (1992). Uczeń niepełnosprawny w szkole powszechnej. Kraków, p. 13.

3 Maciarz, A. (1993). Wspomaganie rodziny w wypełnianiu podmiotowej roli w wychowaniu i rehabilitacji dzieci. In Kostecki, R. - Maciarz, A. (eds.). Podmiotowa rola rodziców w rehabilitacji dzieci niepełnosprawnych. Zielona Góra, p. 33.

4 Maciarz, A. (1999). Op. cit., p. 13.

5 Krause, A. (2000). Integracyjne złudzenia ponowoczesności - sytuacja ludzi niepełnosprawnych. Kraków; Bąbka, J. (2001). Edukacja integracyjna dzieci pełnosprawnych i niepełnosprawnych - założenia i rzeczywistość. Poznań. 
corresponding concepts and interpretations of integration were popular and obligatory at various stages of understanding the idea.

In the forty-year history of popularisation of integration in Poland, significant changes regarding the understanding of the essence of integration but also determinants of its effectiveness have been visible, especially in relation to education. „Both the experience of integration education teachers as well as the results of scientific research and reflections of pedagogues interested in the issues of social integration have been the source of these changes". 6

The most radical changes are related to the following three aspects of integration:

- static/dynamic approach to integration (social integration as a state / social integration as a process),

- individual / social dimension of integration of people with disabilities,

- full / fragmentary nature of social integration. ${ }^{7}$

The first specified aspect concerns transformation in understanding the essence of social integration. Initially (mainly due to the views of A. Hulk) integration was understood as a certain state that can be achieved by leaving people with disabilities in their natural environment and ensuring them easier functioning through appropriate social, organizational, personnel and workshop conditions. It was thought that everything could be prepared before introducing integration. Then all the places, institutions, facilities and devices used by the people witout disability would be made available to the disabled and integration success would be achieved. Nothing could be further from the truth as years of experience have shown. Social integration has appeared as a complicated and multifactorial process, ${ }^{8}$ the process requiring changes in almost all areas of social life. ${ }^{9}$

It is primarily a continuous process, not a one-time move. ${ }^{10}$ It is not an event, a condition that can be introduced quickly, because „the integration rush can only cause discouragement of the pedagogical environment, fears of people with disabilities caused by incomprehensible changes or a lack of understanding of the so-called normal part of society for implemented ideas." ${ }^{11}$ It is also impossible to

6 Maciarz, A. (2001). Przemiany w ujęciu istoty i uwarunkowań społecznej integracji dzieci niepełnosprawnych. In Dryżałowska G. (ed.), Dylematy i przeobrażenia edukacji specjalnej w świetle dorobku profesora A. Hulka. Warszawa, p. 93.

7 Lipińska-Lokś, J. (2011). Zmiany stosunków między dziećmi pełnosprawnymi i dziećmi z niepełnosprawnością w klasach integracyjnych. Zielona Góra; Chrzanowska, I. (2015). Pedagogika specjalna. Od tradycji do wspótczesności. Kraków, pp. 546-547.

Bałachowicz, J. Op. cit., p. 132.

Maciarz, A. (2001), Op. cit., p. 94.

10 Leicester, M. (2000). Integrowanie nierówności: upośledzenia, wiedza i potrzeby specjalne. In Fairbairn, G. - Fairbairn, S. (eds.). Integracja dzieci o specjalnych potrzebach - wybrane zagadnienia etyczne. Warszawa, p. 129.

11 Krause, A. Op. cit., p. 7. 
achieve the state of total stability of social integration. It is the process of positive changes in mutual relations between members of a given group. This dynamic psycho-social process is characterized by emotional engagement of involved people. If children are participants of this process, it requires constant educational support, elimination of disintegrating factors and strengthening of integrating children. ${ }^{12}$ At the same time, it is even necessary to avoid "accidental integration“ such as informal and unsustainable projects, for example in the face of political changes, because all integration projects must be clearly defined, well planned and systematically evaluated in terms of specific benefits for the integrated person. ${ }^{13}$ You also cannot „(...) prepare for social integration once and for all by fulfilling certain conditions before it is introduced. Their preparation is only a preliminary activity for the successful implementation of the process of social integration of disabled children". ${ }^{14}$

This change in the recognition of the essence of social integration of people with disabilities has resulted in broadening understanding of the concept and giving more general dimension to the integration, as it relates to the whole society. Integration of people with disabilities is not only the problem of themselves, despite the fact that they are the basic "addressees of integration activities“. After all, social integration is associated with changes in the socio-cultural environment, in the attitudes and behaviors of people witout disability towards disabled persons as well as providing ,such types of special assistance, devices and situations that would support the development, rehabilitation and social integration of these people". 15 The mere fact of placing a child with disability in the community of children without disabilities and undertaking integration activities assumes that more than one party (not only a child with disability) participates in the integration process. Other children and teachers also participate in this process. The recognition of integration as a dynamic, comprehensive and coordinated process of social, organizational, technical, educational and didactic activities requires the participation of teachers, special educators - employed at school, specialists in education, rehabilitation and social services working for these children. ${ }^{16}$ It is also impossible to omit parents (of children with and without disabilites), whose role (absolute priority in raising children, the most important

12 Maciarz, A. (1998), Psychoemocjonalne i wychowawcze problemy dzieci przewlekle chorych. Kraków.

13 Mittler, P. (2000). Czyje potrzeby? Czyje interesy? In Fairbairn, G. - Fairbairn, S. (eds.). Integracja dzieci o specjalnych potrzebach - wybrane zagadnienia etyczne. Warszawa, p. 67.

14 Maciarz, A. (2000). Przemiany w ujęciu istoty i uwarunkowań społecznej integracji dzieci niepełnosprawnych. Nasze Forum no 1, p. 6; Chrzanowska, I. (2015). Pedagogika specjalna. Od tradycji do współczesności. Kraków.

15 Maciarz, A. (2001). Op., cit., p. 94.

16 Ibid. p. 95. 
link in their managing, influencing them in a socially valuable way) has been finally appreciated thanks to the ongoing changes. ${ }^{17}$

The third aspect of the changes in the recognition of the essence of social integration concerns the issue of integration opportunities for people with disabilities.

Two concepts emerge in the light of the views of persons interested in the social integration of people with disabilities. The first one, (created and disseminated by A. Hulk) is the concept of full, total, unconditional integration. It is expressed in the desire to enable every child with disability to be brought up and taught in his or her natural environment (family, public school, local environment) and to create appropriate conditions for development, upbringing and learning in this environment. This concept is related to the idea of abandoning the organisation of separate special centres in favour of organising various forms of special assistance for the disabled in kindergartens, schools, boarding schools, educational centres, etc. which are open to the public.

The second concept - the concept of fragmentary, partial, limited integration - assumes taking into account the type and degree of child's disability, the condition and possibilities of modern mainstream schools but also economic and social conditions in integration activities. It assumes that the society is complemented only by individuals with lesser disabilities or partially revalued. This concept also means that the education of children and young people in existing segregation insitutions will be modified by introducing various didactic and educational situations in which pupils have the opportunity to make contact with people without disabilities, interact with them, have fun and work together. The concept of fragmentary integration assumes also certain flexibility and openness of the system by allowing a child to move from one form of education to another depending on his or her situation, and thus different degree of integration at a given moment.

It should be added that opposing these two concepts seems unreasonable nowadays as they both assume the diversity of their forms. The existence of only one form of integration could be as rigid as one form of segregated special education has proved to be. ${ }^{18}$ Any path leading to integration can be appropriate,

17 Korzon, A. (2000). Zajęcia korekcyjno - wychowawcze w pracy z dziećmi o specjalnych potrzebach edukacyjnych. In Rakowska, A. - Baran, J. (eds.) Dylematy pedagogiki specjalnej. Kraków, p. 151-152; Korzon, A. (2001). Rodzina młodzieży niesłyszącej jako model jej aspiracji i planów życiowych. In Maciarz, A. - Janiszewska - Nieścioruk, Z. - Ochonczenko H. (eds.). Człowiek niepełnosprawny w rodzinie $i$ w środowisku lokalnym. Zielona Góra, p. 82; Korzon, A. (2001). Specyfika wzajemnych relacji nauczyciel - uczeń w procesie kształcenia dzieci niepełnosprawnych. In Palak, Z. (ed.). Pedagogika specjalna $w$ reformowanym ustroju edukacyjnym. Lublin, p. 99. 
if only the child and his needs, not requirements of the system, will be put in the center of attention while organizing the process of teaching and upbringing. ${ }^{19}$

In the aspect of changes in undersanding the social essence of integration of the disabled, special attention has been paid to the conditions of educational integration regarding the category of children with disabilities.

An essential condition for undertaking integration activities is to establish the proportions between the common features (which constitute the basis for integration) and specific, distinct features (which determine the quality and scope of rehabilitation assistance) of children with disabilities and their non-disabled peers. ${ }^{20}$ "The predominance of common features between people with and without disabilities justifies the appropriateness and value of their social integration". 21

According to A.Hulek, integration can only bring the expected results if it is preceeded by various preparatory activities concerning the integration: revalidation of the individual (maximum improvement of the child's physical, mental and social development), preparation of parents, educators and environment (peers without disabilities) and provision of appropriate scientific and technical assistance. ${ }^{22}$

The effectiveness of social integration of children with disabilities both at school and in the broadly understood social environment is to a large extent also determined by: the attitude of the society towards people with disabilities, the attitude of parents and teachers towards children with disabilities and the degree of their preparation to perform care, educational and didactic activities, the attitude of parents of children without disabilities towards children with disabilities and to the fact of their being in kindergartens and mass schools, maximal improvement of the child (according to his or her ability) and his or her preparation to enter into situations integrating him or her with children without disabilities, selection of an appropriate form of special education for the child, taking into account the child's health situation, developmental possibilities and needs, factors directly related to the process of education and teaching. ${ }^{23}$

19 Dworznikowska, M. (2000). Kształcenie specjalne w województwie warmińsko - mazurskim. In Kosakowski Cz. - Zaorska M. (eds.). Dziecko o specjalnych potrzebach edukacyjnych. Toruń.

20 Hulek, A. (ed.) (1979). Wspótczesne teorie i tendencje wychowania i kształcenia specjalnego. Wrocław; Hulek, A. (1983). Badania naukowe nad osobami niepelnosprawnymi $i$ ich znaczenie dla systemu oświatowego. In Hulek A. (ed.) Funkcja pedagogiki specjalnej w systemie oświatowo - wychowawczym, Ossolineum, Wrocław; cf. A. Hulek - B. Grochmal - Bach (eds.) (1992). Op., cit.; cf. A. Hulek (1993), Kształcenie specjalne w systemie integracyjnym. In Pomykało, W. (ed.), Encyklopedia Pedagogiczna. Warszawa.

21 Janiszewska - Nieścioruk, Z. (2000). Znaczenie samooceny $w$ społecznej integracji dzieci niepełnosprawnych intelektualnie. Zielona Góra, p. 21.

22 Hulek, A. (ed.) (1980). Pedagogika rewalidacyjna. Warszawa, pp. 501-505.

23 Maciarz, A. (1989). Wybrane zagadnienia pedagogiki specjalnej. Materiały dla studentów kierunków pedagogicznych. Zielona Góra; cf. Maciarz, A. (1992). Uczniowie niepetnosprawni w szkole powszechnej. Poradnik dla nauczycieli. Warszawa. 
W. Dykcik points to the model-system approach to the conditions of social integration and presents the following conditions: microsystem - in the area of interpersonal relations in the family and in the local environment (school) as the place of life; mesosystem - regarding supporting institutions; macrosystem related to the hierarchy of social values, norms.$^{24}$

Achieving a high level of social integration is only possible if we ensure proper and comprehensive conditions for its effectiveness. „It is not enough to introduce only some factors conditioning the successful social integration of pupils with disabilities, because the inefficiency of even one of important factors can cause failure, despite the good guarantee of the others". 25

In the period of social integration of children and youth with disabilities, beliefs about the validity of these conditions have changed. It is also a fact that the implementation of these conditions should be included in a dynamic perspective, which demonstrates the need for constant care to ensure appropriate conditions for the effectiveness of integration and the desired impact on its process.

Among basic conditions for successful social integration of children with disabilities, priority is always given to the positive attitudes of children without disabilities towards them and behaviors resulting from this. Formerly it was thought that these attitudes could be developed before introducing "special“ children into their community, but due to the three-dimensionality of attitudes, it is difficult to shape them permanently in isolation from the „object“ they concern.

Good understanding of needs and capabilities of disabled peers, development of empathy and easier acceptance of various behaviors will be possible only by spending time together. ${ }^{26}$ The mere placement of a child with disability in a class group does not guarantee positive relationships between children, especially that there are few situations during a traditional lesson that allow to develop these relationships. In this context, the issue of the need to support the mutual attitudes and behaviours of children in an integration group by initiating situations in which children remain in friendly and equal contact with their peers and have a sense of acceptance and belonging to the group is increasingly discussed.$^{27}$ Extracurricular activities saturated with educational and integrative values to a greater extent than normal lessons can undoubtedly serve to include children with disabilities in the community, to increase their empowerment and thus normalize their social situation. However, at this point

24 Dykcik, W. (1997). Efekty i uwarunkowania integracji społecznej uczniów niepełnosprawnych z rówieśnikami na wsi i w mieście. In Rakowska A. - Pilecki J. (eds.). Stan badań nad kształceniem specjalnym - teraźniejszość i perspektywy. Prace Pedagogiczne XX (Rocznik Naukowo - Dydaktyczny, zeszyt 186). Kraków, p. 9; Gajdzica, Z. (2011). Uczeń $z$ niepetnosprawnościq w szkole ogólnodostępnej, Wyd. Humanitas, Sosnowiec. Dykcik, W. (1979). Wspótpraca szkoły specjalnej ze środowiskiem w zakresie adaptacji społecznej dzieci upośledzonych umysłowo. Poznań. 
a certain problem begins, namely financial resources for organizing such activities. Experience teaches that „some form of additional support is needed, which implies the need for specific funding. Treating integration as a cheap solution is a threat to it". ${ }^{28}$ Granting equal or minimally higher financial means for pupils with and without disabilities cannot be the element of equal treatment.

The approach to the condition of effective integration, which is the proper preparation of a child with a disability for integration, has also changed. It is not possible, as previously thought, to prepare a child properly to function in an integration group before placing her/him in that group. The greatest results of integration are achieved if this process is initiated in the earliest stages of the development of children, both with and without disabilities, when the vulnerability of them to various influences - including integration - is the highest. Also, can children with disabilities be prepared to live among their peers in isolation? Views regarding the "maximum improvement and independence of a child both physically and mentally" 29 before integration as necessary for its prosperity today raise some doubts if we treat integration as a gradual, dynamic process of becoming a child integrated in the group (and not the state achieved by placing the disabled child in the group), the essence of which is the mutual relations and behavior of children without and with disabilities (and not only meeting educational standards) and if we accept the thesis that the concept of total and fragmentary integration is complementary.

The issues concerning a teacher cannot be overlooked in the consideration of changes in terms of social integration conditions of people with disabilities. To the teacher - his appropriate knowledge and skills of providing care, upbringing and teaching, his positive emotional attitude and belief in the value of integation education - was initially assigned an important role in the integration of children with. Currently, these integration conditions related to the person of the teacher are not denied but the needs associated with it are increasingly pointed out. On the one hand, there is a need for a more complete preparation of teachers by equipping them with reliable knowledge in several specialties, so that they can properly include elements of special education into the normal course of school education and that they can provide expert advice, e.g. legal advice to parents of children; ${ }^{30}$

28 Stobart, G. (2000). Czy psychologia potrafi uzasadnić ideę integracji dzieci o specjalnych potrzebach. In Fairnbairn G. (ed.), Integracja dzieci o specjalnych potrzebach - wybrane zagadnienia etyczne.Warszawa, p. 58; cf. Chrzanowska, I. (2015). Pedagogika specjalna. Od tradycji do współczesności. Kraków.

29 Hulek, A. (ed.) (1980). Op., cit., p. 501; cf. Bąbka, J. (2012). Zachowania kooperacyjne w sytuacjach zadaniowych u młodzieży w okresie wczesnej adolescencji. Analiza porównawcza młodzieży pełnosprawnej i z różnymi ograniczeniami sprawności. Zielona Góra, pp. 70-77.

30 Skrzetuska, E. (1995). Pedagog jako organizator kształcenia specjalnego uczniów niedosłyszących. In Sękowska, Z. (ed.). Przygotowanie pedagogów specjalnych do nowych form kształcenia dzieci niepetnosprawnych. Lublin, p. 84. 
on the other hand, special emphasis is placed on supporting teachers by appropriate services and specialists competent in revalidatio of children with disabilities. $^{31}$ In this situation, it must be taken into account the need to employ special educators in schools (as specialists to help) and to pay them properly for their efforts, and not only to appeal to goodwill and the right attitude. ${ }^{32}$ Then the teacher will approach his class with passion, not with grim determination ${ }^{33}$ and thus certainly will serve the idea of integration more because in the process of social integration of children with and without disabilities "pedagogical competence motivated by pedagogy of the heart is the most important. Teachers who are insensitive, indifferent and sometimes reluctant to disability should not be allowed to teach children". 34 The validity of this statement is also confirmed by the research conducted by A. Korzon among deaf pupils from classes VII and VIII and surdopedagogues, which showed that first of all these pupils expect acceptance from their teachers and the didactic skills and characteristic temperament of the teachers are in second place in their expectations. ${ }^{35}$ Besides, if „mutual, friendly attitude, understood as readiness for the specific form of reaction dominates in the relations between the teacher and the pupil, then the processes of adopting and acquiring specific patterns of behaviour", 36 and also prosocial behavior so desirable in the mutual relations between children without and with disabilities in integration groups proceed correctly.

Ensuring these and previously promoted conditions for social integration of children with disabilities into school will allow for a smooth, gradual but effective course of schooling. The condition is that all actions and changes will always be guided by what is the most important - the welfare of every child,with or witout disability. ${ }^{37}$

31 Maciarz, A. (2000). Op., cit., p. 6.

32 Skrzetuska, E. Op., cit.; cf. Lipińska - Lokś, J. (2018). Nauczyciel ucznia z niepełnosprawnością - rozwój kompetencji zawodowych. Edukacja Ustawiczna Dorostych, no 1, pp. 118-130.

33 Kucyper, K. (1995). Aktualne tendencje w terapii dzieci niepełnosprawnych psychoruchowo. In Sękowska, Z. (ed.). Przygotowanie pedagogów specjalnych do nowych form kształcenia dzieci niepełnosprawnych. Lublin, p. 98.

Kuss - Kondrat, A. (1999). Jak ułatwić im życiowy start. Integracja, no 6.

Korzon, A. (1985). Osobowość pedagoga specjalnego w opinii nauczycieli i uczniów. In Prace Pedagogiczne, Kraków; cf. Lipińska - Lokś, J. (2017). Rola nauczyciela we wczesnej edukacji uczniów z niepełnosprawnością. In Kataryńczuk - Mania, L., Magda - Adamowicz, M. Olczak, A. (eds.). Pedagogika przedszkolna - szansą na świadome budowanie potencjału dziecka. Toruń, pp. 185-202.

Korzon, A. (2001), Op., cit., p. 96.

37 cf. Lipińska - Lokś, J. (2015). Aktualne problemy edukacji uczniów z niepełnosprawnością w percepcji nauczycieli w różnych formach kształcenia specjalnego. Kultura - Społeczeństwo Edukacja, no 1, pp. 159-175; cf. Janiszewska-Nieścioruk, Z. - Sadowska, S. (2015). Możliwości „rehabilitacji” aktualnej sytuacji społecznej i edukacyjnej osób z niepełnosprawnością intelektualną. In Żółkowska, T. - Buława-Halasz, J. - Skryplonek, Ł. (eds.). Niepełnosprawność w spirali naukowych rozważań. Pedagogika specjalna - koncepcje i rzeczywistość, vol. X. Szczecin. 
Integration of pupils with disabilities into the educational system can currently be implemented in various forms. The best known form are integration classes, whose functioning is strictly defined by legal acts. ${ }^{38}$ Despite the tradition of integration classes, despite its numerous advantages, unfortunately, its disadvantages are also pointed out. Moreover, changes in European legal regulations and recommendations as well as the experience of reflexive practitioners have resulted in the idea of inclusive education, which is often understood as improved and extended integration of pupils with disabilities in the school system. ${ }^{39}$ In fact, there is a philosophy of inclusion, which assumes that a school providing inclusive education allows every pupil to realize his/her potential, is esteemed, his/her needs are respected, can count on cooperation and help. This school can certainly be described as a "school for all“ because it implements teaching and educational methods adapted to the diversity of its pupils. $^{40}$

The education of pupils with disabilities aims to reduce the role of integration classes in favour of inclusive education. Integration classes - this formal creation with a signboard marking students - although not perfect in the educational system, in special education - makes you believe in the success of inclusive education. It is to be hoped that the implementation of inclusive education will be carried out in full compliance with the idea of inclusion in education, that the needs of every pupil, especially the one with special educational needs, with disabilities will be fully satisfied.

38 Apanel, D. (2017). Teoria i praktyka kształcenia integracyjnego osób z niepełnosprawnościa w Polsce w latach 1989-2014. Kraków, pp. 423-429.

39 Szumski, G. (2006). Edukacja inkluzyjna - geneza, istota, perspektywy. Kwartalnik Pedagogiczny, no 1; cf. Szumski, G. (2011). Teoretyczne implikacje edukacji włączającej. In Gajdzica, Z. (ed.), Uczeń z niepełnosprawnością w szkole ogólnodostępnej. Sosnowiec, p. 16.

40 Booth, T. - Ainscow, M. (eds.) (2000). Indeks for Inclusion. Developing Learning and Participation in Schools, Bristol: CSIE.

Online unter: www.eenet.org.uk/resources/docs/Index\%20English.pdf 